\title{
Monoclonal Antibodies against a Protein Missing from Nonmotile Mutants of the Gliding Bacterium Cytophaga johnsonae
}

\author{
By THOMAS M. TYRE AND JACK L. PATE* \\ Department of Bacteriology, University of Wisconsin, Madison, WI 53706, USA
}

(Received 20 July 1987; revised 18 September 1987)

\begin{abstract}
To identify components of the gliding bacterium Cytophaga johnsonae that are involved in gliding motility, we generated hybridomas that produced monoclonal antibodies (MAbs) against membranes from wild-type cells and screened for MAbs that failed to bind to cells of nonmotile mutants. Of 22 hybridomas generated, three produced MAbs that were positive in ELISA with wild-type cells or their membranes and were negative in ELISAs with 57 of 63 mutants tested. Immunoblots of polyacrylamide gels of wild-type membrane proteins showed that all three of these motility-related MAbs recognized the same antigen: a $40 \mathrm{kDa}$ major membrane protein of wild-type cells. Immunoblots of nonmotile mutant cells and membranes showed that those giving negative ELISA results with the three MAbs actually produced the protein, but in only trace amounts compared with the parental strain. These results show that synthesis of the $40 \mathrm{kDa}$ protein is related somehow to the ability of the cells to move, but the nature of the relationship is still unknown. The protein may be required for motility, or regulation of its synthesis and assembly may be linked to motility although it has no direct role in motility. Results of other experiments on the distribution of an immunologically related protein among other gliding bacteria and on the effects of the three motility-related MAbs on gliding of $C$. johnsonae did not distinguish between these two possibilities.
\end{abstract}

\section{INTRODUCTION}

Some bacteria are unable to swim but are capable of gliding movements when in contact with surfaces (Henrichsen, 1972). Although several theories to explain prokaryotic gliding have been advanced (Burchard, 1984; Keller et al., 1983), the molecular basis of gliding is not known, nor is it known whether the mechanism underlying gliding is the same in all gliding prokaryotes. Although no surface structures required for gliding motility have yet been demonstrated, movements of latex beads over cell surfaces of Cytophaga johnsonae, Flexibacter columnaris and Cytophaga strain U67 have led to suggestions that the machinery of motility consists of a system of rotary assemblies in the cell envelopes (Pate \& Chang, 1979), or a system of moving tracks in the outer membrane of the cells (Lapidus \& Berg, 1982). The pattern of latex-bead movement suggests that the machinery of motility, whatever its nature, is distributed over the entire cell surface and that components of the machinery should constitute major components of envelopes prepared from these cells. Sulphonolipids have been shown (Abbanat et al., 1986) to play a role in gliding of $C$. johnsonae cells, but the nature of their involvement is not understood.

Members of one class of motility mutants of $C$. johnsonae are incapable of any movement and do not move latex beads on their cell surfaces and, for this reason, are considered to have defects in the machinery responsible for gliding (Chang et al., 1984). These mutants are called truly nonmotile (TNM) to distinguish them from other mutants that produce nonspreading colonies but whose cells are motile, as seen by phase-contrast microscopy. All TNM mutants exhibit a

\footnotetext{
Abbreviations: TNM, truly nonmotile; HTC, high tryptone cytophaga; EC, enriched cytophaga; BCIP, 5bromo-4-chloro-3-indolyl phosphate; MAb, monoclonal antibody; FITC, fluorescein isothiocyanate.
} 
curious pleiotropy, becoming phage resistant and changing several surface-related properties, as a result of the nonmotile condition (Chang et al., 1984; Wolkin \& Pate, 1985, 1986).

Some preliminary work (J. L. Pate, unpublished) showed that an envelope fraction prepared from wild-type cells and extracted with DMSO was enriched for proteins that were missing from one or more of the TNM mutants. Reasoning that the missing proteins are likely to be involved in motility, we have used the DMSO-insoluble fraction as antigen to obtain monoclonal antibodies (MAbs) that recognized antigens present in wild-type envelopes but absent from envelopes of TNM mutants, hoping thereby to obtain MAbs specific for motility-related cell envelope proteins.

\section{METHODS}

Strains. The strain designations and origins of the wild-type gliding bacteria used are listed in Table 1. Cytophaga sp. strain U67 (Henrichsen, 1972) and Cytophaga sp. strain GB-2 (Usinger et al., 1985) have not been characterized to species level and are referred to as Cytophaga U67 and Cytophaga GB-2, respectively. Cytophaga johnsonae UW101 is our laboratory strain which was derived from strain ATCC 17061. The truly nonmotile (TNM) mutants used were all derived from $C$. johnsonae UW101 (Chang et al., 1984; Wolkin \& Pate, 1985). The NS-1 myeloma line used for the cell hybridization was obtained from Randall Dimond (University of Wisconsin).

Media. All Cytophaga strains were grown at $25^{\circ} \mathrm{C}$ on high tryptone cytophaga (HTC) medium, $\mathrm{pH} 7 \cdot 0$, which contained (per litre distilled water) $4.0 \mathrm{~g}$ tryptone (Difco), $0.5 \mathrm{~g}$ yeast extract (Difco), $0.5 \mathrm{~g}$ beef extract (Inolex) and $0.2 \mathrm{~g}$ sodium acetate. Broth cultures were grown with shaking in HTC medium. Assays for colony spread were done on enriched cytophaga (EC) agar, which differs from HTC medium only in having half the concentration of tryptone. Myxococcus xanthus strains were grown at $25^{\circ} \mathrm{C}$ in CTT medium (Hodgkin \& Kaiser, 1977). For solid media, Bacto Agar (Difco) was added to HTC, EC and CTT to a final concentration of $1.5 \%(\mathrm{w} / \mathrm{v})$. NS-1 myeloma and hybridoma cell lines were grown in Dulbecco's Modified Eagle's Medium (DMEM, Gibco) supplemented with $20 \%(\mathrm{v} / \mathrm{v})$ foetal bovine serum (Gibco).

Reagents. $p$-Nitrophenyl phosphate, polyethylene glycol $\left(M_{\mathrm{r}}\right.$ approximately 8000 ), Ponceau S, BSA, 2,6,10,14tetramethylpentadecane, 5-bromo-4-chloro-3-indolyl phosphate (BCIP) and nitro blue tetrazolium were obtained from Sigma. Freund's complete adjuvant was purchased from Gibco. Goat anti-mouse $\operatorname{IgG}(\gamma)$ conjugated to alkaline phosphatase, rabbit anti-goat IgG conjugated to alkaline phosphatase and goat anti-mouse $\operatorname{IgG}(\gamma)$ were from Kirkegard \& Perry Laboratories. Pure nitrocellulose was obtained from Bio-Rad. Fluoresceinisothiocyanate-conjugated (FITC-conjugated) anti-mouse antibody was purchased from Tago.

Preparation of membrane fractions. (i) For production of MAbs and for ELISA. Cells were grown to an optical density of 95-105 Klett units (approximately $2 \times 10^{9}$ cells ml $^{-1}$, measured with a Klett-Summerson colorimeter using a red filter), chilled on ice, and harvested by centrifugation at $6000 \mathrm{~g}$ for $10 \mathrm{~min}$. All cell fractions were kep? chilled throughout the membrane isolation. Cells were resuspended in $5 \mathrm{~mm}-\mathrm{MgCl}_{2}$ at $6 \mathrm{ml}$ per $\mathrm{g}$ wet weight of cell pellet. The cells were broken by two passages through a French pressure cell at 12000 p.s.i. (83 MPa). Unbroken cells were removed by centrifugation at $16000 \mathrm{~g}$ for $10 \mathrm{~min}$. The membrane fragments were collected by centrifugation at $150000 \mathrm{~g}$ for $60 \mathrm{~min}$. The pellet was homogenized for $10 \mathrm{~min}$ with a tissue homogenizer in $0.01 \mathrm{M}$ PBS (0.15 M-sodium chloride, 0.15 M-sodium phosphate, $\mathrm{pH} 7 \cdot 3)$ containing $20 \%(\mathrm{v} / \mathrm{v}) \mathrm{DMSO}$ and centrifuged at $150000 \mathrm{~g}$ for $60 \mathrm{~min}$. The pellet was suspended in $1.25 \mathrm{ml}$ PBS per $\mathrm{g}$ wet weight of original cell pellet using a tissue homogenizer. The total protein content was determined by the method of Bradford (1976) using the Bio-Rad rèagent. The suspension was diluted to $250 \mu \mathrm{g}$ protein $\mathrm{ml}^{-1}$ and stored frozen at $-20^{\circ} \mathrm{C}$ in $1 \mathrm{ml}$ samples. This fraction will be referred to as the DMSO-insoluble membrane fraction.

(ii) For immunoblots of membrane proteins. Cells were grown and harvested as in $(i)$. The pellet from $100 \mathrm{mll}$ liquid culture was homogenized in $3.5 \mathrm{ml} 10 \mathrm{~mm}-\mathrm{Tris} / \mathrm{HCl}, \mathrm{pH} 8.0$, and passed through a French pressure cell. The suspension was brought to $8.0 \mathrm{ml}$ with $10 \mathrm{mM}-\mathrm{Tris} / \mathrm{HCl}, \mathrm{pH} 8.0$, and centrifuged for $10 \mathrm{~min}$ at $17300 \mathrm{~g}$. To the supernatant fraction were added $0.8 \mathrm{ml} 0.1 \mathrm{M}$-EDTA, $\mathrm{pH} 7.5$, and $0.8 \mathrm{ml} 10 \%(\mathrm{v} / \mathrm{v})$ Triton X-100, and the suspension was centrifuged at $150000 \mathrm{~g}$ for $1 \mathrm{~h}$. The pellet was homogenized in $0.2 \mathrm{ml} 5 \mathrm{mM}$-EDTA in $10 \mathrm{mM}-$ $\mathrm{Tris} / \mathrm{HCl}, \mathrm{pH}$ 8.0. This fraction will be referred to as the Triton-insoluble membrane fraction.

Production of antibodies. (i) Monoclonal. MAbs were produced following the protocol of Kohler \& Milstein (1975) as modified by Mierendorf \& Dimond (1983). Fifteen-week-old BALB/c mice were given an intraperitoneal injection of a $1: 1(\mathrm{v} / \mathrm{w})$ mixture of the UW101 DMSO-insoluble membrane fraction, containing $25 \mu \mathrm{g}$ protein, and Freund's complete adjuvant. Four weeks later $50 \mu \mathrm{g}$ of the DMSO-insoluble membrane protein was injected intraperitoneally. Over the following 9 weeks an additional eight injections, each containing $25 \mu \mathrm{g}$ protein, were administered intravenously. At $3 \mathrm{~d}$ after the final injection, spleen cells were fused with NS-1 myeloma cells using polyethylene glycol; fused cells were deposited into ten microtitre plates and incubated for 1 week. Hybridomas producing MAbs that bound to the UW101 membrane fraction were identified by ELISA. Monoclonal hybridomas which were positive in two successive ELISAs were obtained by limiting dilutions. A single 
Table 1. Origins of wild-type gliding bacteria

\begin{tabular}{|c|c|}
\hline Strain & Origin \\
\hline \multicolumn{2}{|l|}{ Cytophaga johnsonae } \\
\hline UW101 & ATCC 17061 \\
\hline UW 1012 & ATCC 29583 \\
\hline UW 1013 & ATCC 29584 \\
\hline UW 1014 & ATCC 29586 \\
\hline UW 1016 & ATCC 29587 \\
\hline UW 1018 & ATCC 29588 \\
\hline UW10112 & ATCC 29589 \\
\hline UW $101 \underline{14}$ & ATCC 29590 \\
\hline \multicolumn{2}{|l|}{ UW 10117} \\
\hline \multicolumn{2}{|l|}{ UW 10118} \\
\hline \multicolumn{2}{|l|}{ UW 10119} \\
\hline \multicolumn{2}{|l|}{ UW 10120} \\
\hline \multicolumn{2}{|l|}{ UW 10121} \\
\hline \multicolumn{2}{|l|}{ UW 10122} \\
\hline \multicolumn{2}{|l|}{ UW 10123} \\
\hline \multicolumn{2}{|l|}{ UW 10124} \\
\hline \multicolumn{2}{|l|}{ UW 10125} \\
\hline \multicolumn{2}{|l|}{ UW 10126} \\
\hline \multicolumn{2}{|r|}{ Isolated from soil and water samples, } \\
\hline \multicolumn{2}{|r|}{ Madison, WI, USA } \\
\hline \multicolumn{2}{|l|}{ UW 10129} \\
\hline \multicolumn{2}{|l|}{ UW 10130} \\
\hline \multicolumn{2}{|l|}{ UW 10131} \\
\hline \multicolumn{2}{|l|}{ UW 10132} \\
\hline \multicolumn{2}{|l|}{ UW10133 } \\
\hline \multicolumn{2}{|l|}{ UW 10134} \\
\hline \multicolumn{2}{|l|}{ UW 10135} \\
\hline \multicolumn{2}{|l|}{ UW10136 } \\
\hline \multicolumn{2}{|l|}{ UW 10137} \\
\hline \multicolumn{2}{|l|}{ UW 10138} \\
\hline Cytophaga sp. strain GB-2 & W. R. Usinger* \\
\hline Cytophaga sp. strain U67 & R. P. Burchard $\dagger$ \\
\hline Cytophaga succinicans & E. J. Ordal $\ddagger$ \\
\hline Myxococcus xanthus FB & R. P. Burchard \\
\hline Myxococcus xanthus DK 101 & R. P. Burchard \\
\hline
\end{tabular}

representative monoclonal hybridoma was stored from each cloned line by freezing at $-70^{\circ} \mathrm{C}$. The hybridomas and the MAbs produced by them were named $101 \mathrm{mp} 1$ through $101 \mathrm{mp} 22$. All 22 of these hybridomas produced MAbs of the IgG class since the clones were selected in an ELISA using an anti-IgG $(\gamma)$ conjugated antibody. Ascites fluid was prepared by priming each mouse with $0.5 \mathrm{ml}$ tetramethylpentadecane and 2 weeks later injecting with $2 \times 10^{6}$ hybridoma cells. The collected ascites fluid was brought to $40 \%(\mathrm{w} / \mathrm{v})$ ammonium sulphate using a saturated solution. The precipitate was washed with $40 \%(w / v)$ ammonium sulphate, solubilized with PBS, pH 7.3, and dialysed against PBS.

(ii) Polyclonal rabbit antiserum. Strain UW 101 was grown to late exponential phase, harvested, washed twice by centrifugation with PBS, and suspended in PBS. Approximately $10^{9}$ cells in $1.5 \mathrm{ml}$ were injected subcutaneously into each of two New Zealand White rabbits. Six additional subcutaneous injections were administered over the following 3 months. A final intravenous injection of $2 \times 10^{8}$ cells suspended in PBS was given $7 \mathrm{~d}$ before the blood was collected. The collected blood was clotted and the clot removed before heat inactivation of the antiserum. The inactivated antiserum was stored frozen at $-20^{\circ} \mathrm{C}$ until used.

ELISA. (i) Screening cell fusions. The DMSO-insoluble membrane fraction of UW101 was diluted in PBS, $\mathrm{pH} 7 \cdot 3$, to $10 \mu \mathrm{g}$ protein $\mathrm{ml}^{-1}$, and $50 \mu \mathrm{l}$ were added to each well of a polyvinyl chloride microtitre plate. The plates were refrigerated overnight at $4{ }^{\circ} \mathrm{C}$. The next day the procedure of Mierendorf et al. (1983) was followed, using an alkaline-phosphatase-conjugated goat anti-mouse IgG with $p$-nitrophenyl phosphate to detect antibody binding. 
(ii) PBS-washed cells. MAbs were screened for binding to PBS-washed cells using an assay similar to the above. Cells were grown to an optical density of 100-115 Klett units in $25 \mathrm{ml}$ HTC broth, harvested by centrifugation at $10000 \mathrm{~g}$ for $10 \mathrm{~min}$, washed once in PBS, centrifuged, and resuspended with $20 \mathrm{ml}$ PBS. To each well of a microtitre plate were added $200 \mu \mathrm{l}$ washed cells. For assays in which cells were detergent-solubilized, $20 \mu 10 \cdot 1 \%$ SDS ( $w / v)$ were added to each well. Plates were centrifuged in a Sorvall GLCl tabletop centrifuge at $1000 \mathrm{~g}$ for $10 \mathrm{~min}$ and incubated overnight at $4{ }^{\circ} \mathrm{C}$. After rinsing out the unbound cells, MAbs were added as undiluted hybridoma culture supernates or as a 1 in 500 dilution of ascites fluid. The substrate used was $p$-nitrophenyl phosphate, and developed plates were analysed using a BIO-TEK EIA plate reader at a wavelength of $405 \mathrm{~nm}$. We consider a positive ELISA using whole cells to mean that the antigenic site recognized by the MAb being tested is exposed at the cell surface. A MAb that gives a negative ELISA with whole cells but a positive ELISA with SDSsolubilized cells is considered to recognize antigenic sites not exposed at the cell surface.

Gel electrophoresis and immunoblotting. Proteins from the Triton-insoluble membrane fraction were solubilized in treatment buffer [0.125 M-Tris/HCl (pH 6.8), 4\% (w/v) SDS, $20 \%(\mathrm{v} / \mathrm{v})$ glycerol, $10 \%(\mathrm{v} / \mathrm{v}) 2$-mercaptoethanol], boiled for $2 \mathrm{~min}$, and separated by PAGE by the method of Laemmli (1970), using a $12 \cdot 5 \%$ (w/v) running gel. Wells were loaded with samples containing a total of $5 \mu \mathrm{g}$ protein. Alternatively, $1 \mathrm{ml}$ cells grown to an optical density of $100 \mathrm{Klett}$ units was collected, resuspended in $0.1 \mathrm{ml}$ treatment buffer and boiled for $15 \mathrm{~min}$. A sample of the solubilized whole cell protein was loaded into a well and electrophoresed. Gels which were not immunoblotted were stained with Coomassie brilliant blue.

For gels that were immunoblotted, the separated proteins were electrophoretically transferred overnight at $30 \mathrm{~V}$ to nitrocellulose paper. After transfer, the nitrocellulose paper was processed by immunostaining or by Ponceau $S$ staining for total protein. The immunostaining procedure was that of Knecht \& Dimond (1984), using an alkalinephosphatase-conjugated goat antimouse $\operatorname{IgG}(\gamma)$ and BCIP, except that $0.5 \mathrm{mg}$ nitro blue tetrazolium $\mathrm{ml}^{-1}$ was added to the Tris $/ \mathrm{HCl}$ buffer before adding the BCIP and no agar was overlaid on the nitrocellulose paper. For total protein staining, the nitrocellulose filter was treated for $10 \mathrm{~min}$ with Ponceau $\mathrm{S}$ stain (1 in 200 dilution of Sigma stock) and destained with distilled water.

Wild-type strains of $C$. johnsonae and the five other gliding bacteria that did not show binding of single MAbs were retested using a triple sandwich immunoblot procedure which differed from the above procedure in two ways. First, a mixture of equal amounts of three MAbs was used instead of testing each of the MAbs separately. Second, binding of the MAbs was detected using a goat anti-mouse IgG followed by a rabbit anti-goat IgG conjugated to alkaline phosphatase.

Immunofluorescence. The method for immunofluorescence was adapted from Gambino et al. (1984). Cells were prepared by growth in HTC broth to an optical density of 100 Klett units. Cells sedimented with a microcentrifuge from $1 \mathrm{ml}$ culture fluid were resuspended in a $4 \%(\mathrm{v} / \mathrm{v})$ formaldehyde solution, and incubated for $10 \mathrm{~min}$ at $25^{\circ} \mathrm{C}$. After washing twice by centrifugation with PBS, the cells were resuspended in $100 \mu \mathrm{PBS}$ containing $1 \%$ (w/v) BSA. A $5 \mu$ l sample of this suspension was deposited on the centre of a coverslip and air-dried. To the dried cells, $20 \mu \mathrm{l}$ of an ascites fluid were added and incubated at $37^{\circ} \mathrm{C}$ for $1 \mathrm{~h}$. The coverslip was then rinsed in two $5 \mathrm{~min}$ PBS washes and one $5 \mathrm{~min}$ wash in PBS containing 1\% BSA. On the washed smear were deposited $20 \mu 1$ anti-mouse FITC-conjugated antibody at a 1 in 500 dilution in PBS. After $1 \mathrm{~h}$ incubation the PBS and $1 \%$ BSA washes were repeated. The cells on the coverslip were sealed in 9 parts glycerol and 1 part 200 mm-sodium phosphate buffer at $\mathrm{pH} 8.5$, containing $0.5 \% \mathrm{n}$-propyl gallate. Immunofluorescence was observed with a Leitz microscope.

Effects of MAbs on motility and colony spread. To test the effect of MAbs on the motility of strain UW101, $100 \mu 1$ of a cell suspension at 60-80 Klett units were centrifuged, and the pellet was resuspended in $30 \mu l$ of a 1 in 4 dilution of ascites fluid in phosphate buffer. One drop of the cell suspension was used to prepare a wet mount. The cells were examined with phase-contrast optics at $\times 400$ magnification for the translocational, spinning and pivoting movements typical of motile cells.

The effect of the MAbs on spread of colonies over EC agar medium was investigated by spreading $50 \mu \mathrm{l}$ undiluted ascites fluid or undiluted culture supernate from overgrown hybridomas over the surface of EC agar poured the previous day in $60 \mathrm{~mm}$ diameter Petri plates. For mixtures of the culture supernates prepared from mixing equal amounts of three supernates, $50 \mu \mathrm{l}$ of the mixture were applied. Polyclonal antiserum was tested for inhibition of spread by applying $50 \mu \mathrm{l}$ undiluted immune or preimmune serum. After drying for $2 \mathrm{~h}$ at room temperature, $3 \mu \mathrm{l} \mathrm{UW1} 01$ cells were spotted at the centre of each plate and dried for an additional $1 \mathrm{~h}$. The plates were then inverted and incubated overnight in a moist chamber at room temperature and observed for colony spread.

\section{RESULTS}

\section{ELISA screen for MAbs against motility-related antigens}

Twenty-two hybridomas were isolated, all of which produced MAbs that bound in ELISA to the DMSO-insoluble membrane fraction prepared from UW101 cells. When tested in ELISA 
Table 2. MAbs grouped by their binding to unsolubilized or SDS-solubilized cells of strains UW101 and UW10290

Cells from the late exponential phase of growth were used in ELISAs as untreated or SDS-solubilized cells. MAbs were added as undiluted supernates from tissue cultures. An alkaline-phosphataseconjugated anti-mouse $\mathrm{IgG}$ was used to detect $\mathrm{MAb}$ binding. $p$-Nitrophenyl phosphate was the substrate, and absorbances were read at $405 \mathrm{~nm}$. The values given are means from two identically treated wells. Numbers in parentheses represent the SD of each pair of readings.

\begin{tabular}{|c|c|c|c|c|c|}
\hline \multirow[b]{2}{*}{ Group } & \multirow[b]{2}{*}{ MAb } & \multicolumn{4}{|c|}{ ELISA reading $\left(A_{405}\right)$ for strains: } \\
\hline & & $\begin{array}{c}\text { UW101 } \\
\text { unsolubilized }\end{array}$ & $\begin{array}{l}\text { UW101 } \\
\text { solubilized }\end{array}$ & $\begin{array}{c}\text { UW } 10290 \\
\text { unsolubilized }\end{array}$ & $\begin{array}{l}\text { UW } 10290^{*} \\
\text { solubilized }\end{array}$ \\
\hline 1 & $\begin{array}{l}101 \mathrm{mp} 6 \\
101 \mathrm{mp} 12 \\
101 \mathrm{mp} 20\end{array}$ & $\begin{array}{ll}0.803+(0.011) \\
0.300 & (0.021) \\
0.741 & (0.049)\end{array}$ & $\begin{array}{l}0.601(0.006) \\
0.230(0.009) \\
0.532(0.015)\end{array}$ & $\begin{array}{l}0.009(0.001) \\
0.010(0.001) \\
0.035(0.013)\end{array}$ & $\begin{array}{l}0.014(0.004) \\
0.020(0.012) \\
0.014(0.001)\end{array}$ \\
\hline $2 \ddagger$ & $\begin{array}{l}101 \mathrm{mp} 8 \\
101 \mathrm{mp} 19\end{array}$ & $\begin{array}{ll}0.015 & (0.010) \\
0.011 & (0.003)\end{array}$ & $\begin{array}{l}0.384(0.110) \\
0.186(0.016)\end{array}$ & $\begin{array}{l}0.044(0.003) \\
0.024(0.001)\end{array}$ & $\begin{array}{l}1.327(0.004) \\
0.783(0.005)\end{array}$ \\
\hline $3 \S$ & $\begin{array}{l}101 \mathrm{mp} 2 \\
101 \mathrm{mp} 4\end{array}$ & $\begin{array}{ll}0.791 & (0.089) \\
0.349 & (0.009)\end{array}$ & $\begin{array}{l}0.674(0.002) \\
0.661(0.024)\end{array}$ & $\begin{array}{l}0.803(0.067) \\
0.292(0.018)\end{array}$ & $\begin{array}{l}0.887(0.003) \\
0.521(0.096)\end{array}$ \\
\hline
\end{tabular}

* This strain is representative of the 57 TNM mutants that failed to bind group 1 MAbs in ELISA. All 63 TNM mutants bind all group 3 MAbs and, when solubilized with SDS, bind both group 2 MAbs.

+ In eight control wells which were identical to the test wells except that no MAbs were added, the absorbance varied from -0.009 to +0.022 .

$\ddagger 101 \mathrm{mp} 8$ bound to treated and untreated cells of strains UW10221, UW10268, UW10275, UW10278, UW102101, UW102137, UW102141, UW102154, UW102155 and UW102345; $101 \mathrm{mp} 19$ bound to treated and untreated cells of strains UW102278, UW 102101, UW102154, UW102155 and UW102345. These two MAbs bound to all other strains only after SDS solubilization.

$\S$ This group includes all 17 MAbs that bind to unsolubilized cells of UW101 and all 63 TNM mutants. The Table presents the results of two MAbs from this group.

for binding to whole cells or SDS-solubilized cells of wild-type and TNM mutants, the MAbs were separated into three groups (Table 2). Group 1 MAbs recognized antigenic sites that were exposed at the cell surface (MAbs bound to whole cells as well as to solubilized cells) and that were considered to be motility-related because they gave negative ELISAs with 57 of 63 TNM mutants. Group 2 MAbs recognized antigenic sites that were not exposed at the surface of wildtype cells, binding to SDS-solubilized cells but not to whole cells; this was also the case with most of the 63 TNM mutants tested, but $101 \mathrm{mp} 8$ bound to both treated and untreated cells of ten of the mutants and $101 \mathrm{mp} 19$ bound to treated and untreated cells of five of the same mutants. Group 3 consisted of the remaining $17 \mathrm{MAbs}$, all of which recognized antigenic sites that were exposed at the cell surface of wild-type cells and all 63 TNM mutants. The three MAbs in group 1 were chosen for more detailed study because of their failure to bind to most of the mutants, and they are therefore referred to in the rest of the paper as the motility-related MAbs. These three MAbs were the result of a single fusion.

\section{Immunoblots identifying a motility-related antigen}

(i) Strain UW101. Immunoblots of UW 101 membrane proteins showed that all three motilityrelated MAbs bound to the same major band (Fig. 1). The material in this band stained with Ponceau S (not shown), which indicated that it was a protein. Molecular mass standards were used to estimate the molecular mass of the protein in the major band to be $40 \mathrm{kDa}$. Using $101 \mathrm{mp} 12$, there were several minor bands below the $40 \mathrm{kDa}$ band in immunostained blots of solubilized UW 101 cells or their envelopes. These minor bands could have been derived from the $40 \mathrm{kDa}$ protein or could have been due to epitopes common to the $40 \mathrm{kDa}$ protein and other smaller proteins. The minor bands were shown to be derived from the $40 \mathrm{kDa}$ protein during boiling in SDS-solubilizing solution (Fig. 2). With less than 2 min boiling only the $40 \mathrm{kDa}$ band showed on immunoblots of solubilized whole cells; after 2 min boiling the lower bands appeared on immunoblots and their intensity increased with the length of time the cells were boiled. Similar results were obtained with the Triton-insoluble membrane fraction (not shown). Only a 


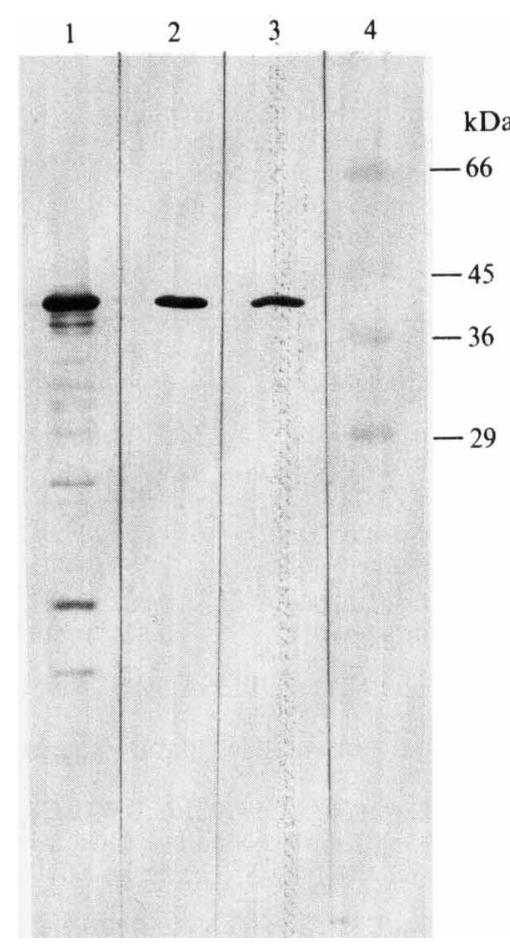

Fig. 1

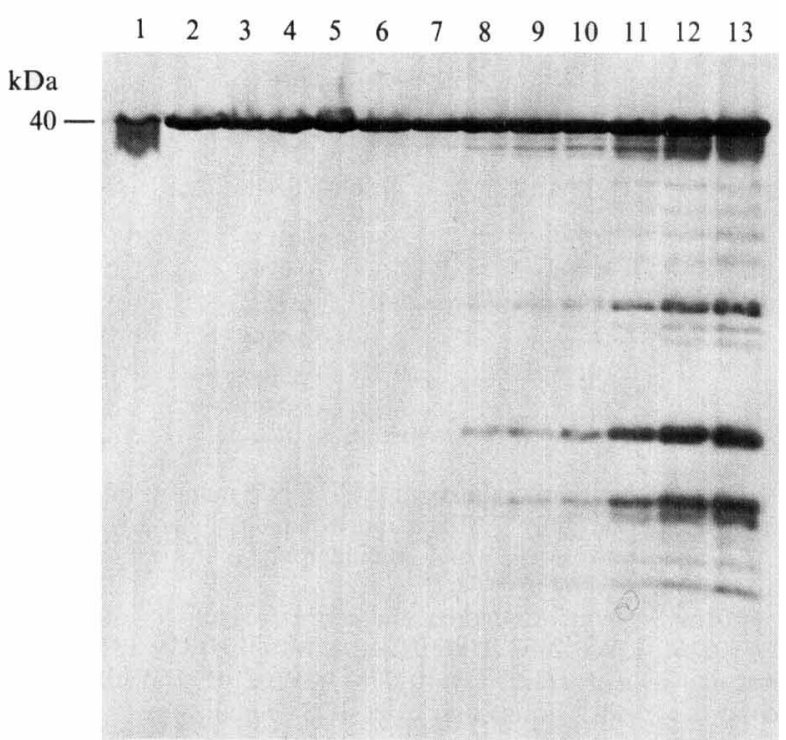

Fig. 2

Fig. 1. Immunoblots of strain UW101 developed with each of the motility-related MAbs. Cells were grown to an optical density of 100 Klett units, collected and solubilized in treatment buffer by boiling for $15 \mathrm{~min}$. Each lane was loaded with $5 \mu \mathrm{l}$ cell protein. Each blot was developed with a single motilityrelated $\mathrm{MAb}$, and binding of the MAb was detected with an alkaline-phosphatase-conjugated goat antimouse IgG and BCIP as substrate. Lane 1, $101 \mathrm{mp} 12$; lane 2, $101 \mathrm{mp} 6$; lane 3, $101 \mathrm{mp} 20$; lane 4, Ponceau $\mathrm{S}$ stain of molecular mass standards.

Fig. 2. Effect of boiling solubilized cells on occurrence of multiple bands in immunoblots of UW 101 . Cells were grown to an optical density of 100 Klett units, collected and resuspended in treatment buffer. The resuspended cells were boiled for different times, and a $5 \mu l$ sample was loaded on each lane. The immunoblot was developed with $\mathrm{MAb} 101 \mathrm{mp} 12$, and binding was detected with an alkalinephosphatase-conjugated goat anti-mouse IgG and BCIP as substrate. Time of boiling: lane 1, $0 \mathrm{~s}$; lane $2,1 \mathrm{~s}$; lane $3,20 \mathrm{~s}$; lane 4, $30 \mathrm{~s}$; lane $5,1 \mathrm{~min}$; lane 6, $2 \mathrm{~min}$; lane 7, $3 \mathrm{~min}$; lane 8, $5 \mathrm{~min}$; lane 9, $10 \mathrm{~min}$; lane $10,15 \mathrm{~min}$; lane $11,30 \mathrm{~min}$; lane $12,1 \mathrm{~h}$; lane $13,2 \mathrm{~h}$.

few of these minor bands were detected by MAbs $101 \mathrm{mp} 6$ or $101 \mathrm{mp} 20$ (Fig. 1), which suggested that these MAbs bound regions of the $40 \mathrm{kDa}$ protein different from that bound by $101 \mathrm{mp} 12$.

(ii) TNM mutants. Triton-insoluble membrane fractions from 63 TNM mutants were tested for binding of $101 \mathrm{mp} 12$ using immunoblots. Six of the mutants (UW1029, UW10215, UW 10218, UW 10221, UW10225 and UW 102348) showed the same pattern seen with UW101: a $40 \mathrm{kDa}$ dark band with light multiple lower bands (Fig. $3 a$ ). These were the same six mutants that in ELISAs bound MAbs $101 \mathrm{mp} 6,101 \mathrm{mp} 12$ and $101 \mathrm{mp} 20$ as well as UW101. The other 57 mutants showed only a weakly staining band at the $40 \mathrm{kDa}$ position and no multiple lower bands. An immunoblot of nine mutants representative of this group is shown in Fig. 3(b). The intensity of staining varied among the mutants, but was similar to that obtained with the UW101 sample diluted 100 -fold. When a gel was heavily loaded with solubilized UW 101 cells or membranes, adjacent wells were contaminated with the $40 \mathrm{kDa}$ protein, which would show up in stained immunoblots (e.g., Fig. 3a). To avoid this effect, which would interfere with screening mutants possessing trace amounts of the protein, the UW101 sample was diluted 100fold before loading onto gels with these mutants. The dilution eliminated visualization of 

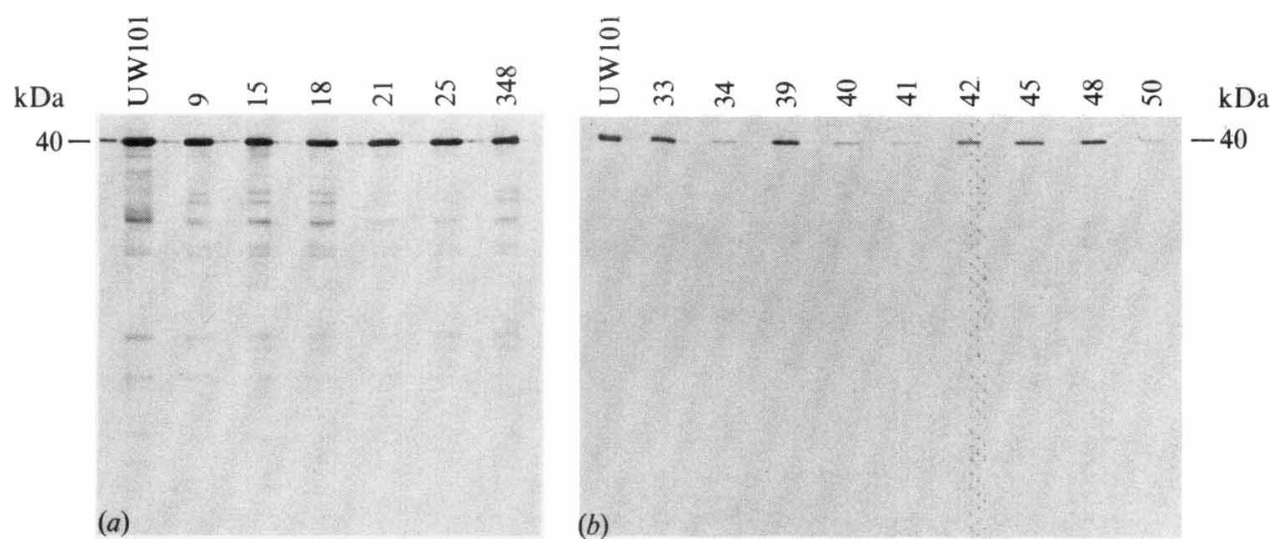

Fig. 3. Immunoblots of strain UW 101 and TNM mutants. Each lane was loaded with $5 \mu \mathrm{g}$ total protein from a Triton-insoluble membrane fraction, except for UW 101 in $(b)$ which was loaded with $5 \mu$ l of a 1 in 100 dilution of solubilized whole cell protein. Proteins were electrophoretically transferred to nitrocellulose membranes, which were probed with MAb $101 \mathrm{mpl} 2$. Binding of $101 \mathrm{mp} 12$ was detected using an alkaline-phosphatase-conjugated goat anti-mouse IgG and BCIP as the substrate. Each lane is labelled with the number of the strain with which it was loaded. Each strain except for UW101 is a TNM mutant and each should have the prefix UW102 as part of its full designation; prefixes were omitted for easier reading of the Figure.

\section{Table 3. Binding of motility-related MAbs by 29 C. johnsonae strains}

Binding was determined using immunoblots. Cells grown to an optical density of $100 \mathrm{Klett}$ units were collected and solubilized in treatment buffer. Each lane of a $12.5 \%$ polyacrylamide gel was loaded with $5 \mu \mathrm{l}$ solubilized cells of one strain. Immunoblotting was as described in Methods. Blots were examined visually for any detectable bands. All strain numbers should be preceded by the prefix UW101. The prefix was omitted for easier reading of the table.

Motility-related MAbs bound

$101 \mathrm{mp} 12$

$101 \mathrm{mp} 6$ and $101 \mathrm{mp} 20$

$101 \mathrm{mp} 6,101 \mathrm{mp} 12$ and $101 \mathrm{mp} 20$

Mixture†
Strains binding

$$
2,3,8,12,17,33,34,36,37,38
$$

18

$19,20,21,22,25,26,28,29$

27

$4,6,14,23,24$

$30,31,32,35$
Position of immunostained band*

Same

Higher

Lower

Higher

Same

Same and lower

* Position relative to $40 \mathrm{kDa}$ band produced by strain UW101.

† These strains did not bind any individual motility-related MAb but were shown to possess a protein antigenically related to the $40 \mathrm{kDa}$ protein of UW 101 using a mixture of the three motility-related MAbs in a triple sandwich immunoblot. Strains $30,31,32$ and 35 showed two bands.

contamination in adjacent lanes and produced a light-staining band with no multiple lower bands.

To test whether the TNM mutants that showed faint immunostaining produce the $40 \mathrm{kDa}$ protein but fail to incorporate it into membranes, whole cells of eight of the mutants were boiled in treatment buffer, run on SDS-PAGE, and tested in immunoblots. Unfractionated cells of all eight mutants gave the same results as their membranes - only weak bands in the $40 \mathrm{kDa}$ position (not shown).

(iii) Other gliding strains. A total of 29 independent isolates of $C$. johnsonae were tested for the presence of proteins antigenically related to the $40 \mathrm{kDa}$ membrane protein of UW 101 by immunoblotting SDS gels of solubilized whole cells with the motility-related antibodies. All 29 strains possessed an antigenically related protein. The strains were placed into four groups based on antibody binding (Table 3). Cells in one group bound only MAb $101 \mathrm{mp} 12$, those of another 


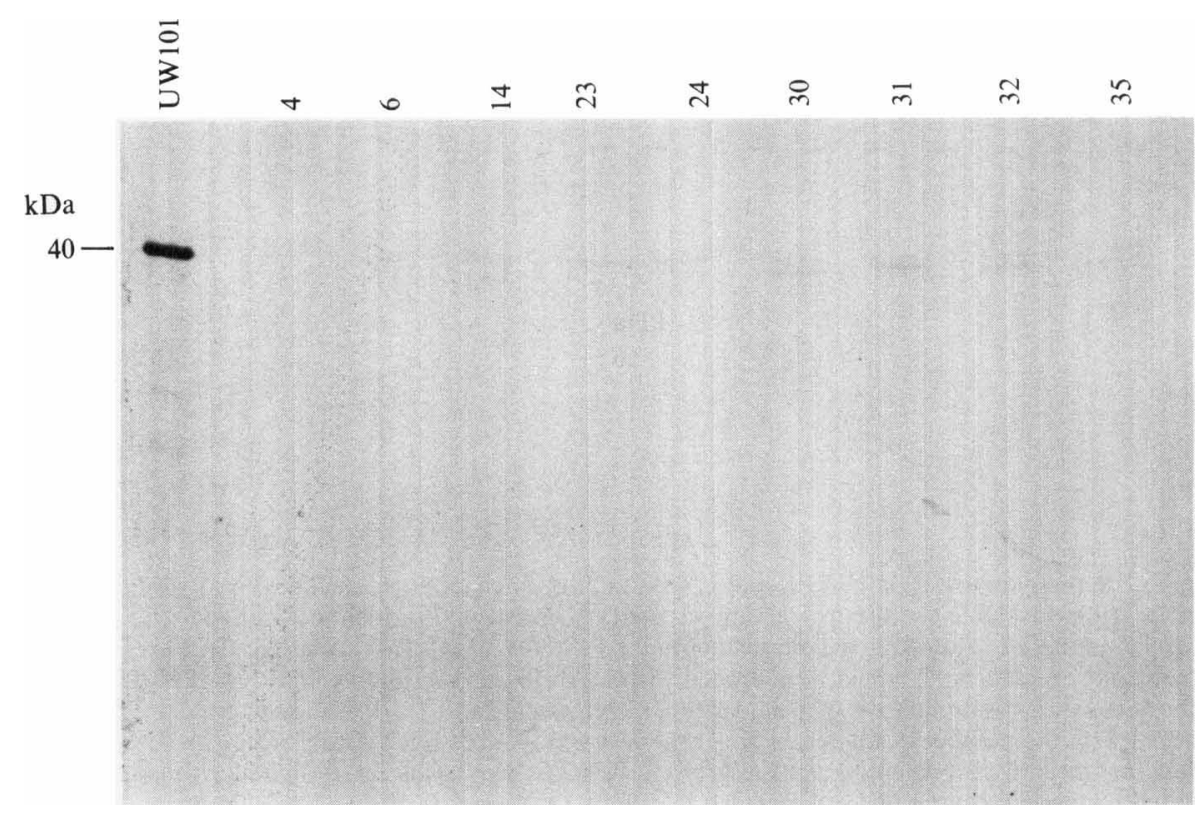

Fig. 4. Immunoblot of strains containing proteins that are antigenically related to the $40 \mathrm{kDa}$ protein of strain UW 101 but can only be detected using a mixture of the motility-related MAbs. Each strain was grown to an optical density of 100 Klett units. Cells were collected and solubilized in treatment buffer by boiling for $2 \mathrm{~min}$. Each lane was loaded with $20 \mu \mathrm{l}$ solubilized cell protein, except the lane loaded with a 1 in 100 dilution of UW101 cell protein which was loaded with $5 \mu$ l. Proteins antigenically related to the $40 \mathrm{kDa}$ protein of UW101 were detected using a mixture of equal amounts of the three motilityrelated MAbs. Binding of the MAbs was detected using a triple sandwich with an alkalinephosphatase-conjugated rabbit anti-goat IgG and BCIP as substrate. Each lane is labelled with the number of the $C$. johnsonae strain with which it was loaded. All strains are wild-type isolates, each of which should have the prefix UW101 as part of its full designation (except UW101).

bound $101 \mathrm{mp} 6$ and $101 \mathrm{mp} 20$ but not $101 \mathrm{mp} 12$, and those of a third group, comprising only strain UW 10127, bound all three motility-related MAbs. Cells of the last group did not bind any of the individual MAbs, but the presence of a protein antigenically related to the $40 \mathrm{kDa}$ protein of UW101 was detected using the motility-related MAbs mixed in equal amounts in a triple sandwich immunoblot procedure (Fig. 4). In all strains the level of staining was weak, being similar to or lower than the intensity of staining seen with MAb $101 \mathrm{mp} 12$ bound to the 58 TNM mutants. Ten of these strains possessed an antigenically related protein slightly shifted in molecular mass from $40 \mathrm{kDa}$ (Fig. 5). Four strains that only showed cross-reaction using the triple sandwich procedure (UW10130, UW10131, UW10132 and UW10135) showed two crossreactive bands, which may have been due to two distinct proteins, each binding one or more of the three MAbs, or the protein in the lower band may have been derived from that in the higher.

Except for the weak double bands observed in the triple-sandwich immunoblots, the results using other strains of $C$. johnsonae reinforced the idea that the motility-related MAbs bind to a single protein. When more than one of the three MAbs bound to immunoblots of any strain, the single band revealed by one MAb was at the same position as that revealed by the others, even when the band was shifted from the $40 \mathrm{kDa}$ position. The results also supported the idea that the motility-related MAbs bind to at least two distinct regions of the $40 \mathrm{kDa}$ protein, an idea first suggested by differences in the multiple banding patterns produced by the three MAbs in immunoblots of UW 101 cells. The MAbs $101 \mathrm{mp} 6$ and $101 \mathrm{mp} 20$, which do not bind to the lower bands of UW101 cells, bind to a different subset of $C$. johnsonae strains than the subset to which only $101 \mathrm{mp} 12$ binds.

In addition to the $29 C$. johnsonae isolates, five other gliding bacteria were screened for the presence of a protein antigenically related to the $40 \mathrm{kDa}$ protein using all three MAbs in ELISAs. ELISA failed to show any binding of the three MAbs to Cytophaga U67, Cytophaga 


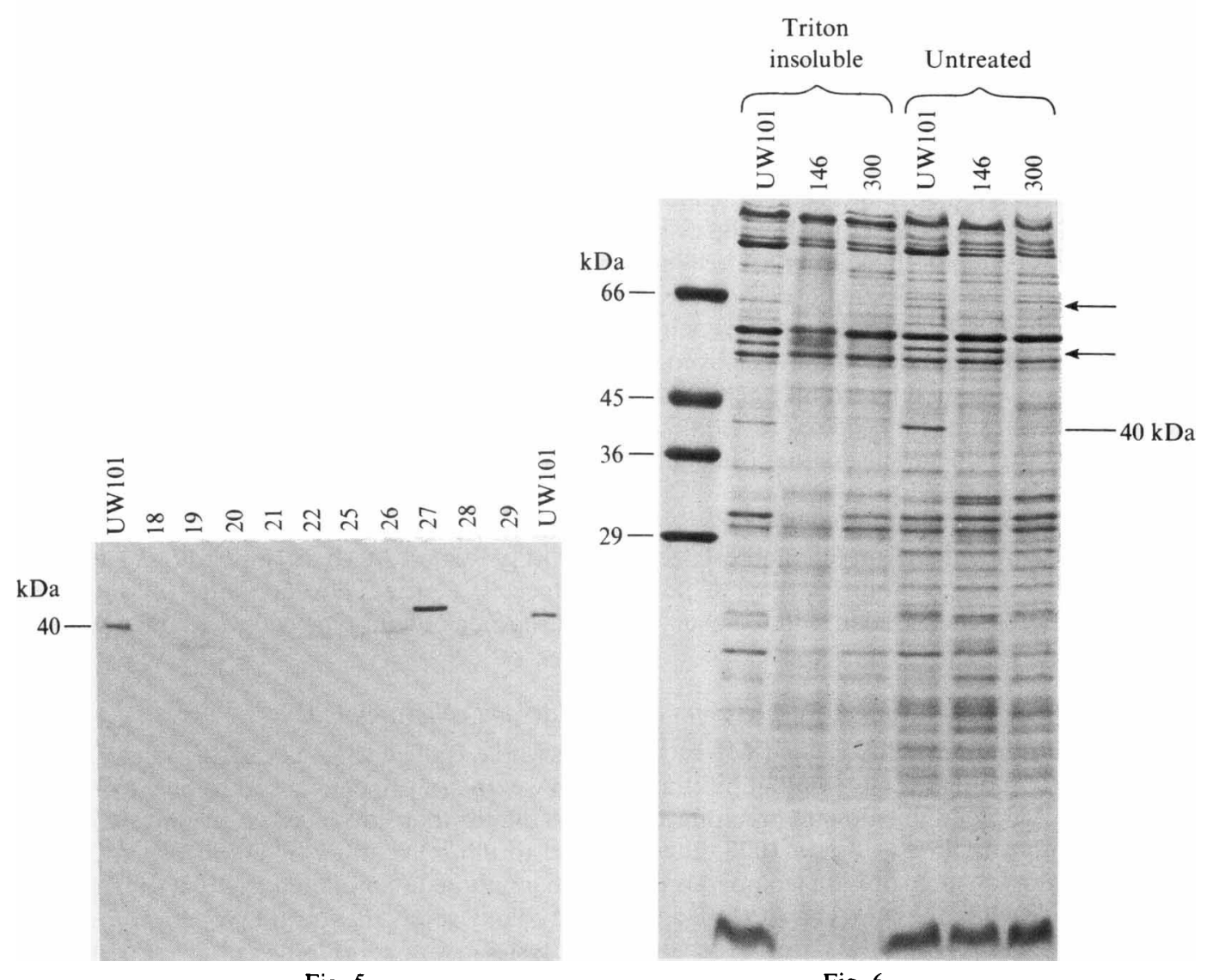

Fig. 5

Fig. 6

Fig. 5. Immunoblot of $C$. johnsonae strains containing proteins that are antigenically related to the $40 \mathrm{kDa}$ protein of strain UW 101 but shifted in molecular mass. Each strain was grown to an optical density of 100 Klett units. Cells were collected and solubilized in treatment buffer by boiling for $15 \mathrm{~min}$. Each lane was loaded with $10 \mu$ l solubilized cell protein, except for strain UW 101. The solubilized protein of UW 101 was diluted 1 in 100 in treatment buffer, and $5 \mu l$ diluted protein were loaded in each of the designated lanes. Proteins antigenically related to the $40 \mathrm{kDa}$ protein of UW101 were detected using $101 \mathrm{mp6}$. Binding of MAb $101 \mathrm{mp} 6$ was detected using a triple sandwich with an alkaline phosphatase-conjugated rabbit anti-goat IgG and BCIP as substrate. Each lane is labelled with the number of the $C$. johnsonae strain with which it was loaded. All strains are wild-type isolates, each of which should have the prefix UW101 as part of its full designation (except UW101).

Fig. 6. Coomassie-blue-stained gel of UW101 and two TNM mutants. Cells were harvested during late exponential growth, broken open, and their membranes collected. Membranes were either extracted with $1 \%$ Triton X-100 or left untreated before solubilizing in treatment buffer by boiling for $2 \mathrm{~min}$. Each lane was loaded with $10 \mu \mathrm{g}$ total protein of either a Triton-insoluble membrane fraction or an unextracted membrane fraction. After SDS-PAGE the gel was stained with Coomassie blue. The strains labelled 146 and 300 are TNM mutants with their full designation including the prefix UW 102. The position of the $40 \mathrm{kDa}$ protein is shown, and two arrows indicate other bands altered in the TNM mutants.

GB-2, C. succinicans, $M$. xanthus FB or $M$. xanthus DK 101, but an immunoblot screen using all three motility-related MAbs mixed together in a triple sandwich revealed $C$. succinicans to have a weakly cross-reactive protein (not shown).

Coomassie-blue-stained polyacrylamide gels of membrane proteins

The weak immunostaining of the $40 \mathrm{kDa}$ protein in TNM mutants could be explained by decreased synthesis of the protein by mutants or by their synthesis of normal amounts of an 
altered protein to which the MAbs bind only weakly. The $40 \mathrm{kDa}$ protein is seen as a major band in Coomassie-blue-stained SDS gels of envelopes prepared from wild-type cells, and the band is missing from those prepared from TNM mutant cells, two examples of which are shown in Fig. 6. Also shown in Fig. 6 is that the $40 \mathrm{kDa}$ protein is partially removed when wild-type envelopes are extracted with $1 \%(\mathrm{v} / \mathrm{v})$ Triton $\mathrm{X}-100$. This was verified by showing that the soluble fraction of Triton-extracted envelopes contained large amounts of the $40 \mathrm{kDa}$ protein as demonstrated by both Coomassie blue staining of the gels or immunostaining of blots of the gels (not shown). Extensive washing of the wild-type envelopes in Tris/ $\mathrm{HCl}$ buffer, $\mathrm{pH} 7 \cdot 2$, or in Tris/ $\mathrm{HCl}$ buffer containing $0.15 \mathrm{M}-\mathrm{NaCl}$, did not release the protein from the envelopes (not shown). The protein profiles of the two mutants differ from each other and from that of wild-type cells in other bands (arrows), as well as in their difference from wild-type cells in the $40 \mathrm{kDa}$ band (Fig. 6). We have examined Coomassie-blue-stained gels of envelopes prepared from all 63 TNM mutants studied here, and the results (not shown) reveal that the 57 mutants that produce only trace amounts of the $40 \mathrm{kDa}$ protein can be distinguished on the basis of differences in other envelope proteins.

\section{Cell surface distribution of the $40 \mathrm{kDa}$ protein}

When examined by immunofluoresence, the motility-related MAb $101 \mathrm{mp} 12$ bound to the entire surface of cells of UW101 but not at all to cells of the TNM mutant 102146. The immunofluorescence was distributed over the entire surface of wild-type cells, with no obvious localization.

\section{Effects of MAbs on cell motility and colony spread}

Since the three motility-related MAbs bound to whole cells, each was tested to determine whether its binding to cells would inhibit motility in wet mounts or colony spread over EC agar medium. Ammonium-sulphate-precipitated ascites fluid that produced a strong positive reaction in an ELISA at a 1 in 1000 dilution failed to inhibit motility of UW101 at a 1 in 4 dilution and failed to inhibit colony spread when undiluted. Undiluted culture supernates containing each of these MAbs also failed to inhibit colony spread of strain UW 101. The effect on motility of UW101 in wet mounts could not be tested using hybridoma culture supernates since the culture supernate from NS-1 myeloma cells inhibited movement in wet mounts. The other 19 MAbs were screened for inhibition of colony spread as six groups of three culture supernates mixed together and one separate supernate. None of the mixtures or the separate supernate inhibited colony spread. Polyclonal rabbit serum against whole cells of UW101 inhibited colony spread over agar, while preimmune serum had no effect. The preimmune serum had no effect on the motility of UW101 cells in wet mounts, but the immune serum agglutinated the cells making it impossible to judge if the cells remained motile.

\section{DISCUSSION}

The immunological approach used in this study resulted in the identification of a $40 \mathrm{kDa}$ protein that is a major component of envelopes of $C$. johnsonae cells and whose synthesis is related somehow to cell motility. The protein behaves as an intrinsic membrane protein, remaining entirely with the washed membrane fraction of broken cells, and being released from washed cell envelopes by treatment with Triton X-100. The fluorescent antibody staining tells us that the protein has a surface-exposed domain that is accessible to antibody binding, suggesting that part of the protein is exposed at the outer surface of the outer membrane. The fluorescent labelling of the entire cell surface and the relatively large amount of the protein demonstrated by PAGE indicate that the protein is distributed over the entire cell surface.

Of the TNM mutants tested, $90 \%$ produced the $40 \mathrm{kDa}$ protein in greatly reduced amounts, as shown by weak staining in immunoblots. Based on intensity of staining, the amount of $40 \mathrm{kDa}$ protein produced by these mutants is decreased from wild-type amounts by 100 -fold or more. The protein is probably not altered in any of the mutants, since the positions of the bands in immunoblots are not shifted from the $40 \mathrm{kDa}$ region. The weak immunostaining is due to decreased synthesis of the protein instead of alteration of its antigenic properties because the 
protein stains intensely with Coomassie blue in gels of solubilized wild-type membranes but is not detectable by Coomassie blue staining of gels of membranes from mutants of the group with weakly immunostaining bands. Furthermore, cells of this group of mutants do not simply fail to incorporate the protein into cell envelopes, accumulating it in the cytoplasm instead, since immunoblots of unfractionated wild-type cells reveal large amounts of the protein but only trace amounts were seen in all eight unfractionated mutant cells examined this way.

Why do so many of our independently isolated TNM mutants fail to produce the $40 \mathrm{kDa}$ protein in wild-type amounts? All of these mutants share an unusual pleiotropy that is inevitably associated with the inability to move, but unlike those characteristics, reduced synthesis of the $40 \mathrm{kDa}$ protein is not an inevitable consequence of the nonmotile condition, since $10 \%$ of the mutants tested produced wild-type levels of the protein. Furthermore, these mutants can be distinguished from each other on the basis of differences in patterns of bands of membrane proteins on SDS-PAGE. From these considerations it seems probable that a mutation in any one of many genes could result in the TNM phenotype, and that most such mutations affect the synthesis of the $40 \mathrm{kDa}$ protein. The observations that none of the mutants fails altogether to make the protein and that in no case was the faint band in immunoblots of a mutant shifted to a new position argue against these mutants having lesions in the structural gene coding for this protein. A possibility that cannot now be ruled out is that synthesis of the $40 \mathrm{kDa}$ protein is coregulated with motility, but the protein has no direct role in motility. This seems unlikely, but if true it would be an interesting phenomenon: what is the protein's function and why is it regulated this way? Another, more interesting, possibility is that the $40 \mathrm{kDa}$ protein is required in motility and that it is incorporated late in the stepwise assembly of the motility machinery. Synthesis of the $40 \mathrm{kDa}$ protein might then be regulated so that the protein is not made if the complex onto which it must assemble is not completed, and any mutation that prevents synthesis of a component needed earlier in assembly than the $40 \mathrm{kDa}$ protein would repress synthesis of the $40 \mathrm{kDa}$ protein. This is the way that synthesis of components of the flagellar apparatus of some flagellated prokaryotes is regulated: $f l a$ mutants can result from mutations in any of several genes, always causing repression of flagellin synthesis (Komeda, 1986; Bryan et al., 1987).

Results of our attempts to obtain evidence regarding the requirement of the $40 \mathrm{kDa}$ protein in motility were inconclusive. If the protein is required for motility, then binding MAbs to it might be expected to inhibit motility, but the MAbs against the $40 \mathrm{kDa}$ protein had no effect on cell movement or colony spread. This could be the result whether or not the protein is required for motility since attachment of the MAbs to the epitopes recognized by them need not interfere with function of the protein. Demonstration of an immunologically related protein of approximately the same size in independent isolates of $C$. johnsonae showed that the protein is conserved among all these strains tested, although the MAbs did not bind as well to the proteins of these strains as to that of UW101, and in some cases the size of the protein was shifted. Failure to find an immunologically related protein in strains of the other gliders tested does not necessarily mean that a related protein is not made by those strains since the epitopes recognized by the three MAbs we used may not be conserved. Polyclonal antiserum to the purified $40 \mathrm{kDa}$ protein will be valuable for answering this question, as well as for testing its ability to block motility.

The immunological approach has not previously been applied to the study of motility-related antigens in gliding bacteria, although there is a report of MAbs generated against cell surface antigens of the gliding bacterium $M$. xanthus (Gill \& Dworkin, 1986). The goal of that project was to identify development-related antigens, and there was no evidence that the antigens identified played a role in motility.

It should be noted that the $40 \mathrm{kDa}$ protein is produced by wild-type cells in such large amounts that its presence or absence in mutants can be determined simply using Coomassie-blue-stained SDS gels of cell envelopes. The advantage of the immunological approach is that one can tell if the protein is not made, made in reduced amounts, or altered and consequently shifted to a new position in the gel. Further application of the immunological method should result in isolation of hybridomas whose MAbs are directed towards other motility-related proteins, allowing their identification and isolation. 
This research was supported by the College of Agriculture and Life Sciences, University of Wisconsin, Madison, USA, and by grant DCB-8607871 from the National Science Foundation.

\section{REFERENCES}

Abbanat, D. R., Leadbetter, E. R., Godchaux, W.\& ESCHER, A. (1986). Sulfonolipids are molecular determinants of gliding motility. Nature, London 324, 367-369.

BRADFORD, M. M. (1976). A rapid and sensitive method for the quantitation of microgram quantities of protein utilizing the principle of protein-dye binding. Analytical Biochemistry 72, 248-254.

Bryan, R., Champer, R., Gomes, S., Ely, B. \& SHAPIRO, L. (1987). Separation of temporal control and trans-acting modulation of flagellin and chemotaxis gene in Caulobacter. Molecular and General Genetics 206, 300-306.

BURCHARD, R. P. (1984). Gliding motility and taxes. In Myxobacteria: Development and Cell Interactions, pp. 139-161. Edited by E. Rosenberg. New York: Springer-Verlag.

Chang, L.-Y. E., Pate, J. L. \& Betzig, R. J. (1984). Isolation and characterization of nonspreading mutants of the gliding bacterium Cytophaga johnsonae. Journal of Bacteriology 159, 26-35.

Gambino, J., Bergan, L. G. \& Morris, N. R. (1984). Effects of mitotic and tubulin mutations on microtubule architecture in actively growing protoplasts of Aspergillus nidulans. Journal of Cell Biology 99, 830-838.

GILl, J. S. \& Dworkin, M. (1986). Cell surface antigens during submerged development of Myxococcus xanthus examined with monoclonal antibodies. Journal of Bacteriology 168, 505-511.

HENRICHSEN, J. (1972). Bacterial surface translocation: a survey and a classification. Bacteriological Reviews 36, 478-503.

HodGKin, J. \& KaISER, D. (1977). Cell-to-cell stimulation of movement in nonmotile mutants of $M$ yxococcus. Proceedings of the National Academy of Sciences of the United States of America 74, 2938-2942.

Keller, K. H., Grady, M. \& DworkIN, M. (1983). Surface tension gradients: feasible model for gliding motility of Myxococcus xanthus. Jounral of Bacteriology 155, 1358-1366.

KNECHT, D. A. \& DIMOND, R. L. (1984). Visualization of antigenic proteins on Western blots. Analytical Biochemistry 136, 180-184.

KOMEDA, Y. (1986). Transcriptional control of flagellar genes in Escherichia coli K-12. Journal of Bacteriology 168, 1315-1318.

Kohler, G. \& Milstein, C. (1975). Continuous cultures of fused cells secreting antibody of predefined specificity. Nature, London 256, 495-497.

LAEMMLI, U. K. (1970). Cleavage of structural proteins during the assembly of the head of bacteriophage T4. Nature, London 227, 680-685.

LAPIDUS, I. R. \& BERG, H. C. (1982). Gliding motility of Cytophaga sp. strain U67. Journal of Bacteriology 151, 384-398.

Mierendorf, R. C., JR, Cardelli, J. A., Livi, G. P. \& Dimond, R. L. (1983). Synthesis of related forms of the lysosomal enzyme $\alpha$-mannosidase in Dictyostelium discoideum. Journal of Biological Chemistry 258, 5878-5884.

MIERENDORF, R. C., JR \& DimOND, R. L. (1983). Functional heterogeneity of monoclonal antibodies obtained using different screening assays. Analytical Biochemistry 135, 221-229.

Pate, J. L. \& Chang, L.-Y. E. (1979). Evidence that gliding motility in prokaryotic cells is driven by rotary assemblies in the cell envelopes. Current Microbiology 2, 59-64.

Usinger, W. R., Clark, G. C., Gottschalk, E., Holt, S.\& Mishell, R. I. (1985). Characteristics of bacterium GB-2, a presumptive Cytophaga species with novel immunoregulatory properties. Current Microbiology 12, 203-208.

Wolkin, R. H. \& Pate, J. L. (1985). Selection for nonadherent or nonhydrophobic mutants co-selects for nonspreading mutants of Cytophaga johnsonae and other gliding bacteria. Journal of General Microbiology 131, 737-750.

Wolkin, R. H. \& Pate, J: L. (1986). Phage adsorption and cell adherence are motility-dependent characteristics of the gliding bacterium Cytophaga johnsonae. Journal of General Microbiology 132, 355-367. 